\title{
INFORMATION DESIGN IN THE PANDEMIC PROCESS
}

\author{
İrem GÜRSU*1 \\ * Öğr. Gör. Düzce Üniversitesi, İletişim ve Tanıtım Koordinatörlüğü / Hacettepe Üniversitesi Güzel Sanatlar \\ Enstitüsü Grafik Anasanat Dalı Sanatta Yeterlik Programı Öğrencisi
}

\begin{abstract}
With the development of technological tools and digital platforms, classic channels in mass communication are quickly replaced by new generation digital channels. The rapidly changing agenda can be followed instantly with YouTube channels, Whatsapp groups, social media platforms such as Facebook, Instagram, Twitter or instant news applications that can be installed on phones. While some of the news in this bombardment attracts attention instantly, even if there are important developments, it can be closed and passed without seeing many news and information. In order to reach the recipient quickly and effectively, the information design has an important position. With the World Health Organization declaring a pandemic on March 11, 2020, Covid 19, which causes panic all over the world, has great importance while the information received on the subject is important. The aim of the study is the importance of the information design, which plays an active role in meeting the need for accurate information during the pandemic process.

In this context, the development and usage areas of the information design, the importance of correct and rapid information sharing during the pandemic process and the communication channels used are discussed. In this process, while examining the digital platforms and information graphics that are most used in our country, the designs that emerged, the public spots that take into consideration the public health, the designs containing the individual designers as a result of the feeling that they feel responsible about the subject, and the designs containing the messages were examined.
\end{abstract}

Keywords: Information Design, Pandemic, Visual Communication Design

\section{PANDEMI SÜRECINDE BILGILENDIRME TASARIMI}

\section{Özet}

Teknolojik araçların ve dijital platformların gelişmesi ile kitle iletişiminde klasik mecralar yerini hızla yeni nesil dijital mecralara bırakmaktadır. Youtube kanalları, Whatsapp grupları, Facebook, Instagram, Twitter gibi sosyal medya platformları ya da telefonlara yüklenebilen anlık haber uygulamaları ile hızla değişen gündem anlık takip edilebilmektedir. Bu bilgi bombardımanı içinde kimi haberler anında dikkat çekerken içinde çok önemli gelişmeler bile barındırsa birçok haber ve bilgi de görülmeden kapatılıp geçilebilmektedir. İletilen bilginin hızlı ve etkili bir şekilde alıcıya ulaşabilmesinde bilgilendirme tasarımı önemli bir konumdadır. Dünya Sağlık Örgütü'nün 11 Mart 2020'de pandemi ilan etmesiyle tüm dünyada paniğe neden olan Covid 19 ile herkesin önceliği değişirken konu hakkında alınan bilgiler büyük öneme sahiptir. Pandemi sürecinde doğru bilgiye duyulan ihtiyacın giderilmesinde aktif rol üstlenen bilgilendirme tasarımının önemi çalışmanın amacını oluşturmaktadır.

Bu kapsamda bilgilendirme tasarımının gelişimi ve kullanım alanları, pandemi sürecinde doğru ve hızlı bilgi paylaşımının önemi ve kullanılan iletişim mecraları ele alınmıştır. Bu süreçte ülkemizde en çok kullanılan dijital platformlar ve bilgilendirme grafiğine intiyaç duyulan alanlar incelenirken, ortaya çıkan tasarımlar, toplum sağlığını göz önünde bulunduran kamu spotları, bireysel olarak tasarımcıların konuyla ilgili kendilerini sorumlu hissetmeleri sonucu yayınladıkları kurallar, tavsiyeler, mesajlar içeren tasarımlar incelenmiştir.

Anahtar Kelimeler: Bilgilendirme Tasarımı, Pandemi, Görsel İletişim Tasarımı

\footnotetext{
${ }^{1}$ Sorumlu Yazar email: iremgursu@duzce.edu.tr / Doi: 10.22252/ijca.752535
} 


\section{Giriş}

İlk olarak Çin'in Wuhan kentinde ortaya çıkan ve 11 Mart 2020 tarihinde Dünya Sağlık Örgütü tarafından pandemi ilan edilen ve henüz hakkında çok az bilgiye sahip olunan Covid-19 virüsü ile neredeyse tüm dünya evine kapandı. Güvenilir ve hızıı bilgi akışının temel bir gereklilik olduğu bu dönem, bilgilendirme tasarımını en çok ihtiyaç duyulan iletişim yöntemi/tasarım disiplini haline getirmektedir. İnternetin neredeyse tek iletişim ve bilgi kaynağı olarak kullanılması ve herkes tarafından hızlı ve kolay ulaşılabilir olması, henüz çok az bilimsel veriye sahip olunan virüs hakkında doğru bilgiler kadar yanlış bilgilerin de yayılmasına neden olurken birçok doğru öneri ve fikrin de yanlış anlaşılmasına yol açmaktadır.

Seçkin bir topluluğun elinde tuttuğu ve tarih boyunca sahip olanlara güç veren bilgi, son yıllarda gelişen teknoloji ve iletişim sistemleri sayesinde artık kolaylıkla ulaşılabilen temel bir ihtiyaç haline gelmiştir. Kısa bir süre öncesine kadar sınırlı ve erişimi zor olan bilginin günümüzde katlanarak artması insanların ihtiyaç duyduğu kadarını bile almasını zorlaştııırken yoğun bir şekilde artan bilginin içinden gerekli olanların hızlı ve etkili şekilde iletilmesi intiyacı doğmakta ve bu noktada bilgilendirme tasarımı devreye girmektedir (Güler, 2008:1-2).

Illetişim intiyacını Pektaş Turgut; "Insan, çevresinde olup bitenleri öğrenmek, başına gelenleri çevresine duyurmak ve fikirlerini başkalarına iletmek." (2009: 89) biçiminde ifade etmektedir. Özellikle tüm dünyayı tehdit eden ve sağlık gibi önemli bir konuda ortaya çıkan bu kriz döneminde paylaşılan her bilgi hayati önem taşımaktadır. Bu noktada tasarımcılar, verileri anlaşılır ve etkili bir dille görselleştirip yayınlarken, bilginin kaynağını oluşturan bilim ve sağlık uzmanları kadar büyük bir sorumluluk bilincinde olmalıdır. Eğitimli, eğitimsiz, zengin, fakir, çalışan, işsiz herkesi ilgilendiren ortak bir konuda özel bir hedef kitlenin değil, bütün insanların aynı mesajı görüp anlayabileceği bir iletişim dili kullanılması gerekmektedir.

Özellikle son yıllarda hızı bir şekilde artış gösteren ve hayatımızın vazgeçilmez parçası olmaya başlayan akıllı telefonlar ile bilgiye erişim hızlanıp kolaylaşırken aynı oranda bilgi alma yoğunluğu da artmaktadır. Telefon ve bilgisayarlara kurulan programlar, kullanılan sosyal medya hesapları, anlık sohbet uygulamaları gibi kanallardan gün içinde gelen ve bizi bakmaya, dinlemeye ve tepki vermeye zorlayan ileti bombardımanı içinde bazı bilgiler daha önemliyken diğerlerinin arasında kaybolup gidebilmektedir. Oysa ki bu bilgilerin anlaşılmaması ya da yanlış anlaşıması büyük problemlere yol açabilmektedir. "Şu çok açık ki modern dünyada herkesin anlayabileceği organize bir şekilde, yazıımış ve sunulmuş bilgilendirme tasarımına ihtiyaç vardır" (Spiekermann, 2009:44).

\section{Bilgilendirme Tasarımı}

Son yıllarda hızlanan teknolojik ve bilimsel gelişmelerin artışı birçok açıdan hayatı kolaylaştırırken yoğun bilgi bombardımanını da beraberinde getirmektedir. Yazılı ve görsel verilerin artması ve giderek karmaşıklaşması bilginin sunumunu da önemli bir noktaya taşırken görsel iletişim tasarımının ötesinde yeni bir disiplin olarak bilgilendirme tasarımının doğmasını zorunlu hale getirmektedir. "Bilgilendirme tasarımı, grafik tasarımın özünde var olan bilgilendirmeyi bir ileri adıma taşır" (Güler, 2008:16).

Horn, bilgilendirme tasarımını tanımlarken "bilginin, insanlar tarafından etkin ve verimli olarak kullanılmasına olanak verecek şekilde hazırlanma sanatı ve bilimidir." (Horn, 2009: 30) der ve bilgilendirme tasarımının temel hedeflerini üç madde olarak açıklar:

1. "Anlaşılabilir, hızlı ve doğru bir şekilde düzeltilebilir ve kolayca etkin eyleme dönüştürülebilecek belgeler geliştirmek.

2. Ekipmanla olabildiğince kolay, doğal ve keyif verici etkileşimler tasarlamak. Bu; etkileşimli arayüz tasarımında birçok sorunun çözülmesini sağlar.

3. İnsanların, rahatık ve kolaylıkla üç boyutlu boşlukta yön/yol bulmalarını sağlamak (özellikle kentsel alanlarda; fakat son gelişmelere bakıldığında sanal alan da bu kapsama dahil edilebilir)" (Horn, 2009: 30).

Schuller'e göre ise bilgilendirme tasarımı; "karmaşık verilerin, iki boyutlu görsel sunumlara dönüştürülerek, bilginin; iletişim, belgeleme ve korunmasını amaçlamaktadır. Bireyin gördüğünün değil bildiğinin gösterimleridir" (Schuller, 2007).

Aslında bilgilendirme tasarımının temelleri insanlık tarihinin en eski görsel öğeleri ya da sanat eserleri olan mağara resimlerine dayansa da bir uzmanlık alanı olarak tanımlanması 90'lara denk gelmektedir. Bilgi 
verme, kayıt tutma, güç gösterisi ya da ibadet etme gibi amaçlarla yapıldığı tahmin edilen ilk mağara resimlerinden günümüze kadar iletişim yöntemi olarak göstergeler daima kullanılmıştır. Mağara resimleri hiyerogliflere, ideogramlara onlar da fonetik yazı sistemlerine dönüşmüş, bilgiyi en hızlı şekilde paylaşma ihtiyacı daima yeni çözüm arayışlarını beraberinde getirmiştir (Jean, 2018, 16 s.).

“illk örneklerinden 20. yüzyıla kadar geçen süreçte veri haritaları ve istatistiksel grafiklerin temelini attığı ve temsil ettiği bilgilendirme tasarımı, 20. yüzyılın ikinci yarısına doğru grafik tasarımın da katkısıyla çeşitlenerek pek çok üründe ve hayatın hemen her alanında kendini göstermeye başlamıştır" (Güler, 2008:57). Artan bilgi kalabalığında bilgilendirme tasarımına hayatın birçok alanında ihtiyaç duyulmaktadır. Gündelik hayatta karşılaşılan birçok mekândan ulaşım sistemlerine, sergileme tasarımları, formlar, dokümanlar, afiş, dergi, broşür gibi ürünlerde yoğun olarak kullanılmaktadır.

Bilgilendirme tasarımı ve grafik tasarım birbirlerinin alt dalı gibi görünüp aynı amaç ve hedefe sahip olsalar da aslında bir arada hareket eden iki disiplinden bahsedilmektedir. İki disiplinin özünde de hedef kitleye göre içeriği belirleyip mesajı görselleştirme olsa bile, bilgilendirme tasarımı daha yoğun bilgiye sahiptir. Grafik tasarımın özünde önce dikkat çekmek varken bilgilendirme tasarımının temel amacı yoğun verileri hedef kitlenin anlayabileceği şekilde görselleştirmektir (Uyan Dur, 2011:6). Yoğun bilgi barındıran bilgilendirme tasarımı ürünleri büyük bir titizlikle ele alınmalıdır. Diğer tüm tasarım disiplinleri gibi bilgilendirme tasarımı süreci bir problemden oluşur ve tasarımcı bilgi birikimi, görgüsü, deneyimi ve yaratıcılığı ile ortaya koyduğu ürünle bu problemi bilinçli ve kontrollü bir şekilde çözmelidir. "Bilgilendirme tasarımı, kullanıcıların belirlenen gereksinimleri doğrultusunda, mesajın taşıyacağı içeriğin ve sunulacağı ortamın belirlenmesi, planlanması ve biçimlendirilmesidir" (Güler, 2008:8).

Bilgilendirme tasarımında göz önünde bulundurulması gereken önemli etmenlerden biri de hedef kitledir. Bir ürün tasarlanırken kullanıcıların tercihleri, alışkanlıkları, amaçları ve deneyimleri göz önünde bulundurulmalıdır. "Bilgilendirmeye yönelik bir çalışmanın başarısı onun hedef kitlesi tarafından doğru algılanması, anlaşılmasıyla ölçülmektedir. Bilgilendirme amaçlı tasarımlarda sosyo-kültürel olgular, eğitim düzeyi, davranış biçimleri, fiziksel engeller, dil, yaş, cinsiyet, inanç farkları vs. insanlar arasında farklı algılamalara, okumalara ve gereksinimlere neden olabilmektedir" (Oral, 2009: 46).

Görsel iletişim tasarımı gibi bilgilendirme tasarımı da karmaşık verileri düzenleyen ve algılanmasını kolaylaştıran bir araç olmasının yanında başka konularda da pek çok kazanımlar

Sağlamaktadır. Hem görsel hem içerik olarak iyi hazırlanmış bir çalışma hedef kitleyi ikna etmek, yönlendirmek ve harekete geçirmek için de güçlü bir araçtır.

\section{Covid-19 ile Gelen Pandemi ve Bilgilendirme Tasarımı}

"Pandemiler veya pandemik hastalıklar, bir kıta hatta tüm dünya yüzeyi gibi çok geniş bir alanda yayılan ve etkisini gösteren salgın hastalıklara (epidemilere) verilen genel addır" (tr.wikipedia.org). Aralık 2019'da ilk olarak Çin'in Hubei bölgesinin başkenti olan Vuhan şehrinde ortaya çıkan yeni tip bir koronavirüs 7 Ocak 2020'de Covid-19 olarak adlandırılmıştır. Avrupa, Kuzey Amerika ve Asya Pasifik'te yer alan birçok ülkeye yayılan virüs nedeni ile 11 Mart 2020'de Dünya Sağlık Örgütü tarafından pandemi ilan edilmesi tüm dünyada paniğe neden olmuştur (COVID-19, 2020:7).

Ülkemize ilk vaka 8 Mart 2020'de görülürken Dünya Sağlık Örgütünün pandemi ilan etmesinin ardından virüsün yayılmasını engellemek için sağlık bakanlığı bir dizi alınması gereken önlem ve uyulması gereken kural yayınlamıştır. Dünya çapında bir salgın olması ve yayılma hızı insanları korkutup ve paniğe neden olurken güvenilir kaynaklardan gelen bilgiler hayati önem taşımaktadır. Virüsün tedavisinin ya da aşısının olmaması, kuluçka süresinin uzun bulaşıcılığının yüksek olması gibi nedenlerden dolayı mümkün olduğunca herkesin evlerinde kaldığı bu süreçte toplu alanlarda bulunurken sosyal mesafe, maske takma ya da sürekli elleri yıkama gibi toplumun her kesimini ilgilendiren bilgilere herkesin ulaşabilmesi, anlaması ve uygulamasını sağlamak bir zorunluluk haline gelmiştir. Bu noktada böyle hassas ve stresli bir dönemde doğru ve etkili bilgi aktarımı için bilgilendirme tasarımı devreye girmektedir.

Özellikle sağlık ile ilgili yapılan bilgilendirmelerin içeriğinin doğru olması kadar doğru anlaşılması da hayati önem taşımaktadır. Varsayımlar ya da kulaktan dolma bilgilerle hareket etmek yerine, araştırarak, doğru kaynaklardan güvenilir bilgiler ışığında, konunun uzmanı ile birlikte çalışıp elde edilen verileri görselleştirmek, hedef kitleyi doğru yönlendirebilmesi için oldukça önemlidir. "Bilgilendirme tasarımı hedef kitle alıcılarının bilgi gereksinimini karşılamak amacıyla, mesajın analizini, planlanmasını, sunuluşunu ve anlaşılmasını 
kapsar. Seçilen kitle ne olursa olsun, iyi tasarlanmış bilgilendirme tasarımı çalışması, estetik, ergonomik, ekonomik olacak ve konu kapsamındaki gereksinimleri karşılayabilecektir" (Pettersson, 2015: 11).

Tüm dünyanın aynı hassasiyete sahip olduğu ve korktuğu pandemi sürecinde herkesin doğru ve güvenilir verilere ulaşabilmesi tasarımcıların sorumluluğundadır. "Tasarım ve tasarımcının toplumdaki rolünün artması ve tasarımın bir toplumsal araç niteliği kazanması sonucu, grafik tasarımcının toplumsal sorumluluğu kavramı gündeme geldi. Çünkü modern grafik tasarım, ne kadar güçlü bir iletişim sağlıyorsa, toplum üzerindeki etkisi o kadar artmaktadır. Bu gelişmelerle birlikte 'görsel iletişim' kavramı grafik tasarımın gündemine girmiştir. Bu deyim grafik tasarımcının, teknolojik ve toplumsal gelişmelerle birlikte, toplumsal rolünün daha fazla önem kazanmasını ifade etmektedir" (Karamustafa, 2003: 57).

Bilgiyi hedef kitleye hızlı ve kalıcı şekilde aktarma, anlaşılırlı̆ı kolaylaştırma ve dikkat çekme özelliklerinden dolayı tasarımda görsel anlatım önemli bir yere sahiptir (Teker, 2009:145). Bilgiyi görselleştirmek, özellikle yoğun ve karmaşık bilgilerin düzenlenmesi, daha etkili ve kalıcı olmasını sağlamak için temel bir gerekliliktir (Görsel 1).

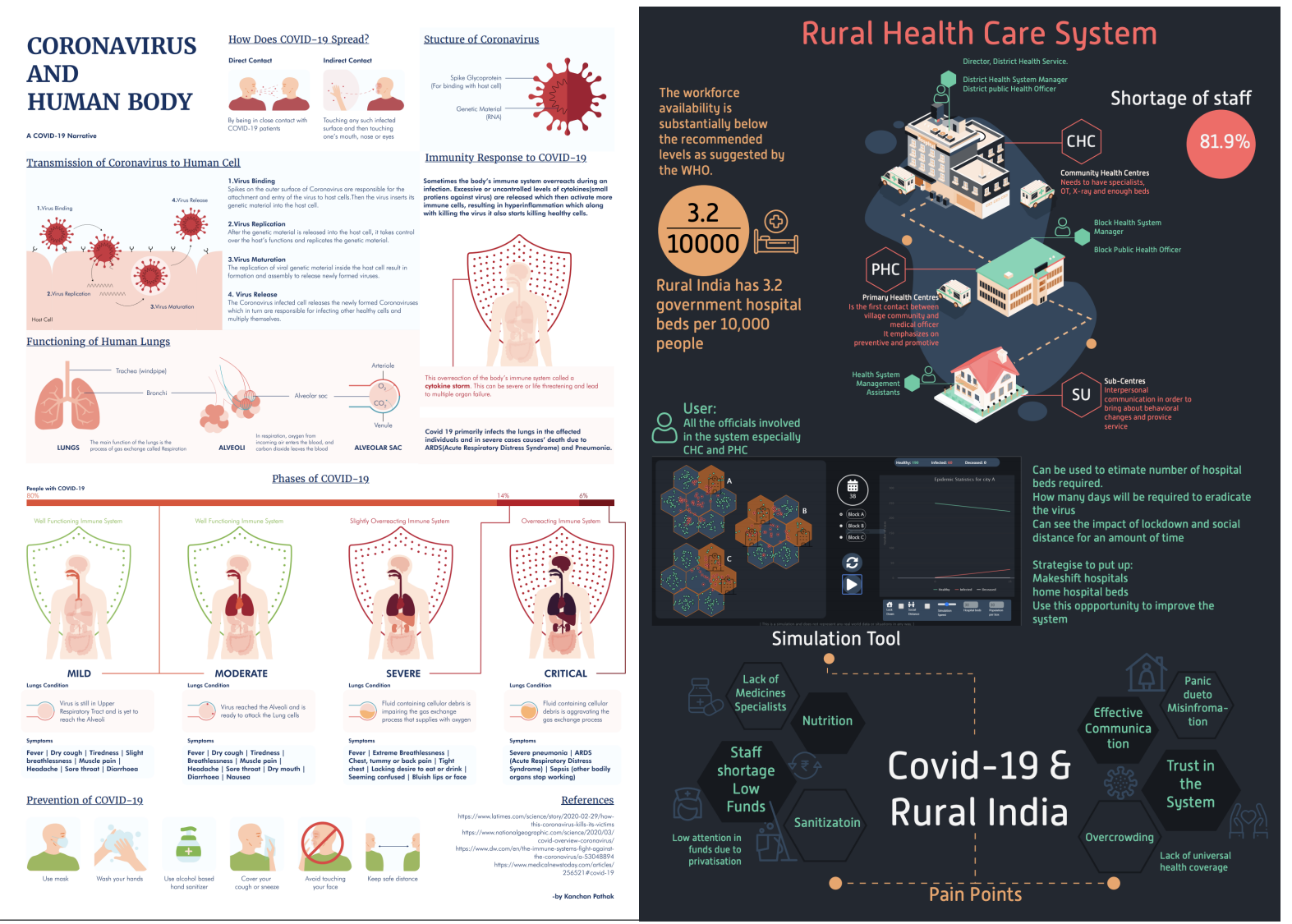

Görsel 1: International Call: D'source Corona Design Challenge. Corona ile ilgili farklı tasarım kategorilerine sahip uluslarası yarışmada bilgilendirme tasarımı kategorisini kazanan, Kanchan Pathak ve Shalaka Sontakke'a ait çalışmalar, 2020

Bilgi bombardımanının içinde olduğumuz internet çağında doğru bilgiler kadar yanlış bilgiler de hızla yayılmakta ve toplum sağlığını tehlikeye atabilmektedir. İlk çıktığı dönemde hakkında hiçbir şey bilinmeyen ve hızla yayılan COVID-19 yüzünden panikleyen halk korunmak için duyduğu ya da gördüğü her bilgiyi uygulamaya çalışmış ve yayılan birçok yanlış bilgi yüzünden insanların sağlığı bozulmuş hatta ölümler gerçekleşmiştir. Örneğin "saf alkol virüsleri öldürüyor" başılılı paylaşımlar sonucu birçok insan saf alkol içerek komaya girmiştir.

Yine ilk dönemlerde, virüsün ilk dört gün boğazda bekleyip sonrasında akciğerlere indiği ve tuzlu ya da sirkeli su ile bu süreçte gargara yapıldığı taktirde boğazın virüsten temizlendiği bilgisi en çok paylaşılan haberlerden olmuştur. Oysa ki tavsiye edilen yöntemin Covid-19 ile mücadelede etkili olduğuna dair hiçbir bilimsel çalışma bulunmamaktadır (teyit.org). 
INONU UNIVERSITY JOURNAL OF CULTURE AND ART / IJCA

İnönü Üniversitesi Kültür ve Sanat Dergisi

Volume/Cilt: 6 No/Sayı: 1 (2020) 1-13

Virüsün hızlı yayılması nedeniyle halkı bilinçlendirmek, panik ve korkunun önüne geçebilmek için de yapılan bilgilendirmelerin doğruluğu kadar hızlı bir şekilde hazırlanıp yayınlanması gerekmektedir. Bu nedenle dünya çapında Dünya Sağlık Örgütü, ülkemizde de Sağlık Bakanlığı süreci doğru yönetebilmek ve halkın korku ve stresini azaltmak adına bütün iletişim mecralarını etkin ve hızıı bir şekilde kullanmışlardır (Görsel 2-3).

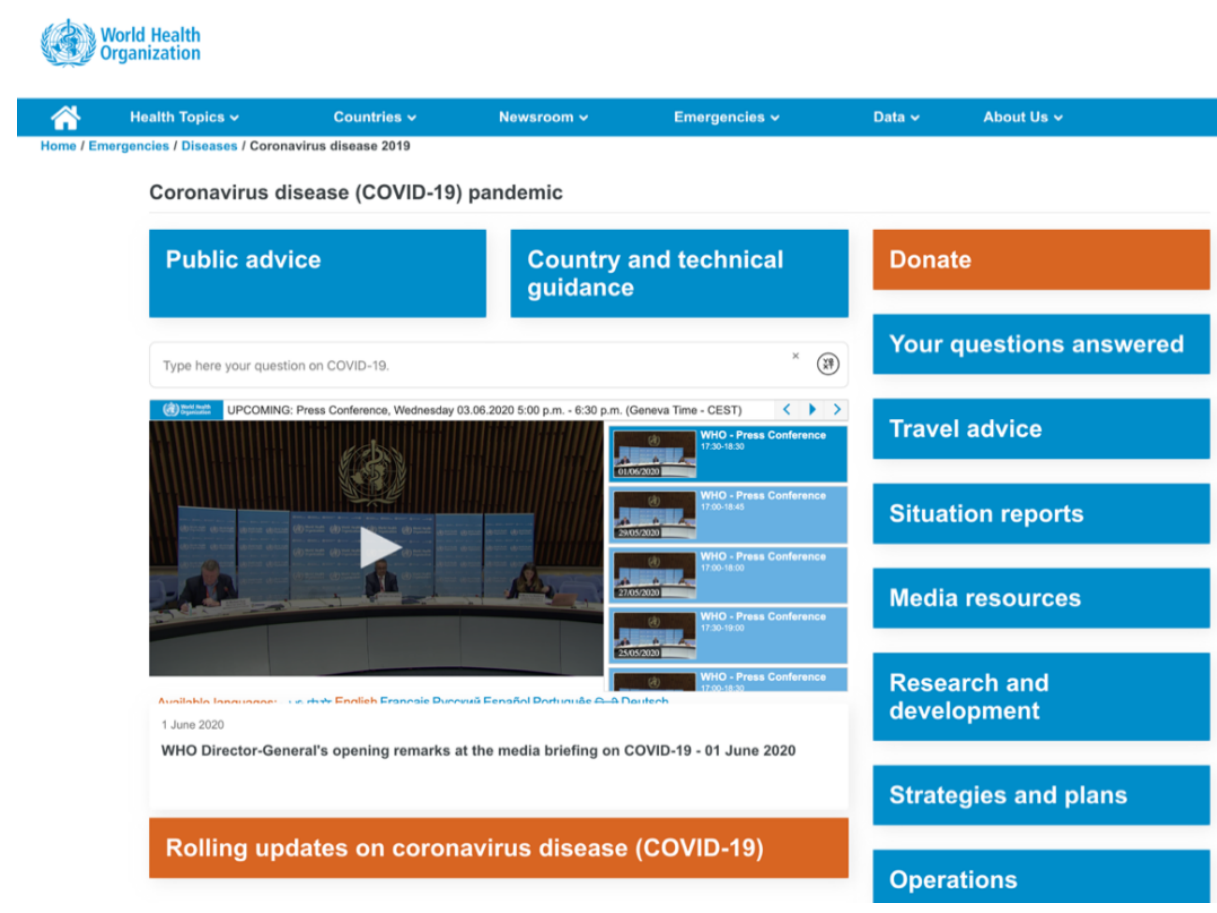

Görsel 2: Dünya Sağlık Örgütü'nün Covid-19 ile ilgili bilgilendirme bölümü, 2020

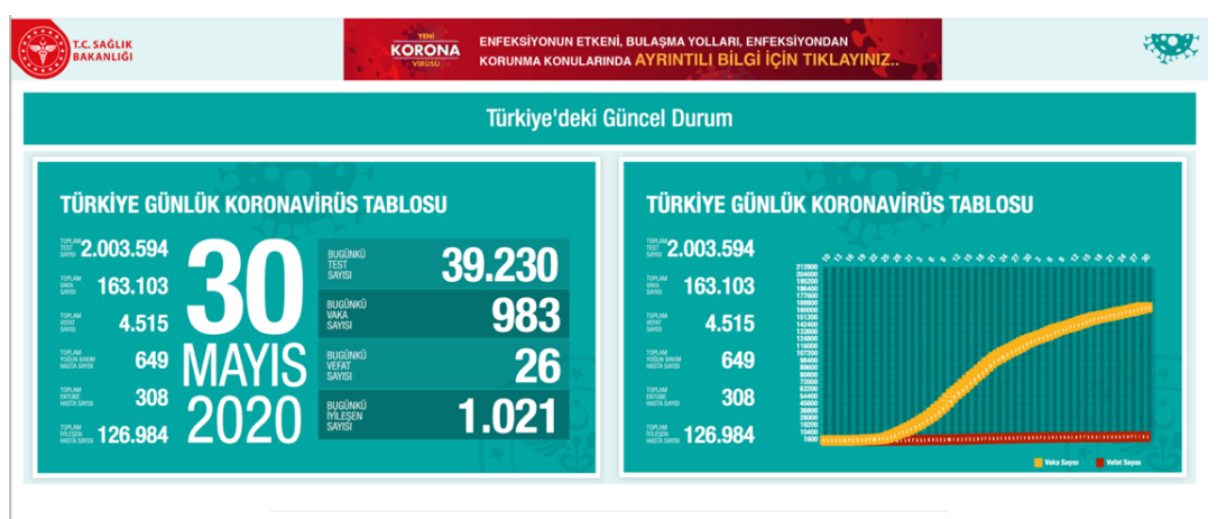

Görsel 3: T.C. Sağıık Bakanlığı'nın yayınladığı ve anlık hasta ve iyileşen sayısının gösterildiği grafik, 2020

Ülkemizde de ilk vakaların görülmeye başlamasından itibaren Sağlık Bakanlığı konu ile ilgili tüm bilgi ve verileri sıcağı sıcağına tüm medya kanallarından paylaşmış ve birkaç gün içinde Covid-19 ile ilgili uyarı ve bilgilendirme billboardları sokaklarda yerini almıştır. Ayrıca tüm kamu kurum ve kuruluşlarına, işyerlerine, konuyla ilgili bilgilendirme afişleri, broşürler ve kitapçıklar hem baskılı hem dijital olarak dağıtılmıştır. Sağlık bakanlığı kendi internet sitesi üzerinden Cavid-19 ile ilgili düzenli bilgi paylaşımlarının yapıldığı bir bölüm yayınlayıp bütün bilgilendirme materyallerini de isteyen herkesin ulaşabileceği şekilde site içinde yayınlamıştır (Görsel 4-5). 


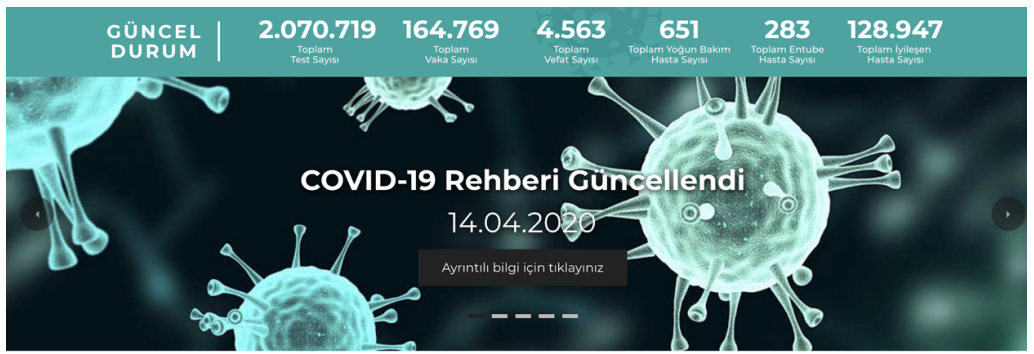

Yeni Koronavirüs Hastalığı (COVID-19)

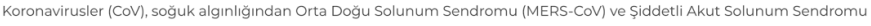

(SARS-CoV) gibi daha ciddi hastallklara kadar çeșitli hastallklara neden olan büyük bir virüs ailesidir

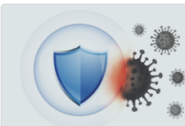

Sağllk Kurumlarında
Enfeksiyon Kontrol
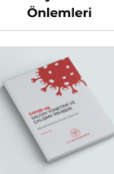

Salgun Yonetimi ve
Çalısma Rehberi

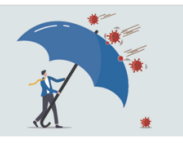

Toplumda
Salgin
Yonetimi

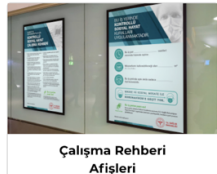

Afișleri
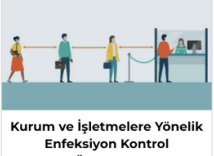

\section{अंखें}

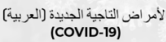

الأمراض التاجية الجديدة (العربية)
(COVID-19)

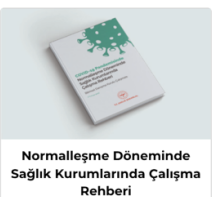

क्ष.

CoviD-19
English Documents

CoviD-19
English Documents

Görsel 4: T.C. Sağlık Bakanlığı sitesinde bulunan Cavid-19 bölümü, 2020

Halka Yönelik

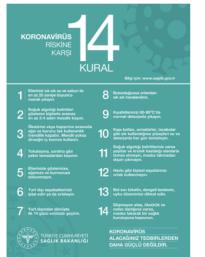

Yeni Koronavirüs Riskine Karș

14 Kural
Afis $1-50 \times 70$

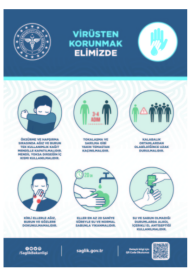

Virüsten Korunmak

Elimizde

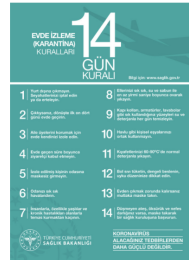

Evde Izleme (Karantina)
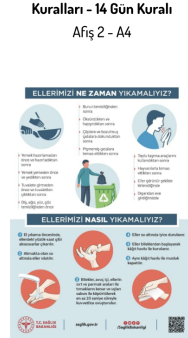

Ellerimizi Ne Zaman ve Nası Yikamalyyz?
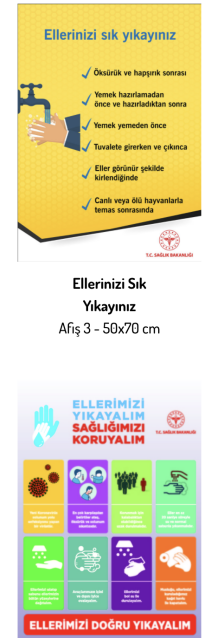
Sağıı̆ı̆ıııı Koruyalım

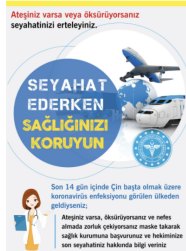

Seyahat Ederken Sağlı̆̆ııııı Korvyun
Afis $4-50 \times 70 \mathrm{~cm}$

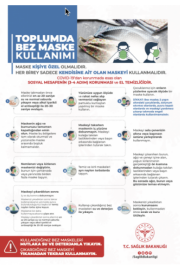

Kullanımı
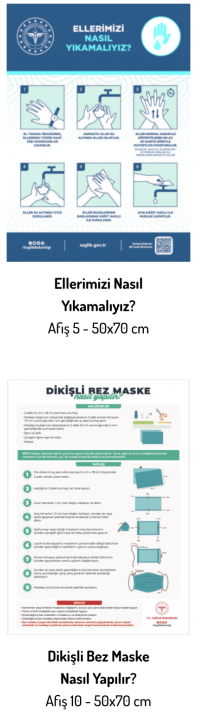

Görsel 5: T.C. Sağlık Bakanlığı sitesi içindeki bilgilendirme materyalleri, 2020

John Hopkins Üniversitesi'nin yayınladığı interaktif bilgilendirme haritası, dünya çapında virüsün bulunduğu ülkeler, toplam vaka sayısı, iyileşen ve ölen insan sayısı, virüsün yayılma hızı gibi birçok verinin doğru ve anlaşılır şekilde ulaşılabildiği başarılı örneklerden biridir (Görsel 6). Genel olarak tüm dünya üzerinde bulunan virus yoğunluğunun yanısıra seçilen ülke hakkında detaylı bilgiye de ulaşılabilmektedir. 


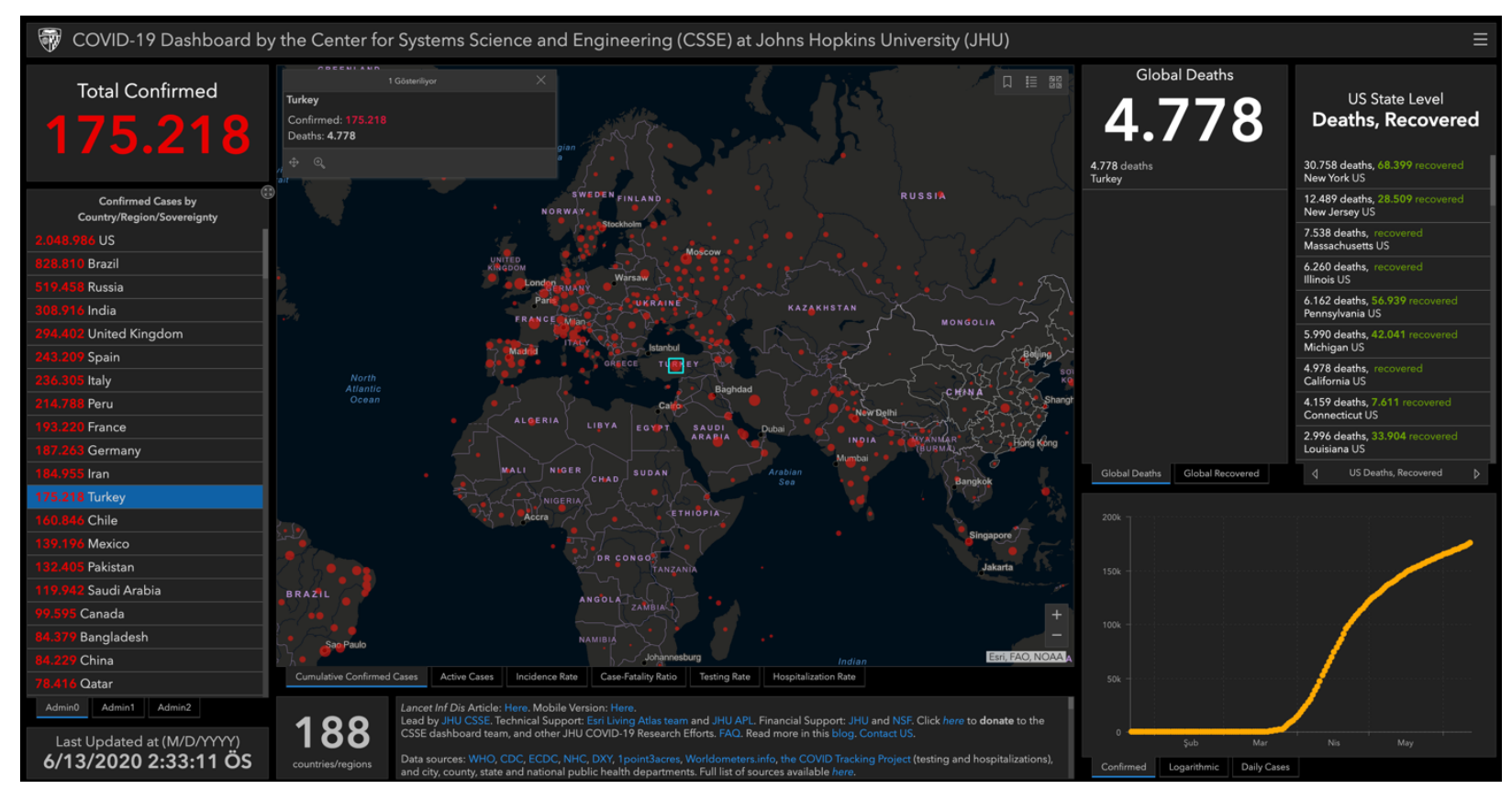

Görsel 6: John Hopkins Üniversitesi'nin hazırladığı Covid-19 bilgilendirme sitesi, 2020

Birçok kamu kurum ve kuruluşları ve birçok işyeri uzaktan ya da dönüşümlü çalışma sistemine geçerken eğitim kurumları da uzaktan eğitim sistemine geçmiştir. Bu süreçle ilgili bilgi ve kararlar çok hızlı değişip güncellenirken çalışan ve öğrencileri bu bilgi bombardımanından en hızlı ve etkili şekilde haberdar edebilmek için bilgilendirme tasarımının gücünden yararlanılmıştır (Görsel 7). "Bilgilendirme tasarımını diğer tasarımlardan ayıran değerler; iletişimsel amacın yerine getirilmesindeki "verimlilik" ve "etkinliktir". İhtiyacımız olan daha fazla bilgi değil, doğru bilgiyi doğru insanlara, doğru zamanda, en verimli ve etkin biçimde sunmaktır" (Horn, 2009: 30).

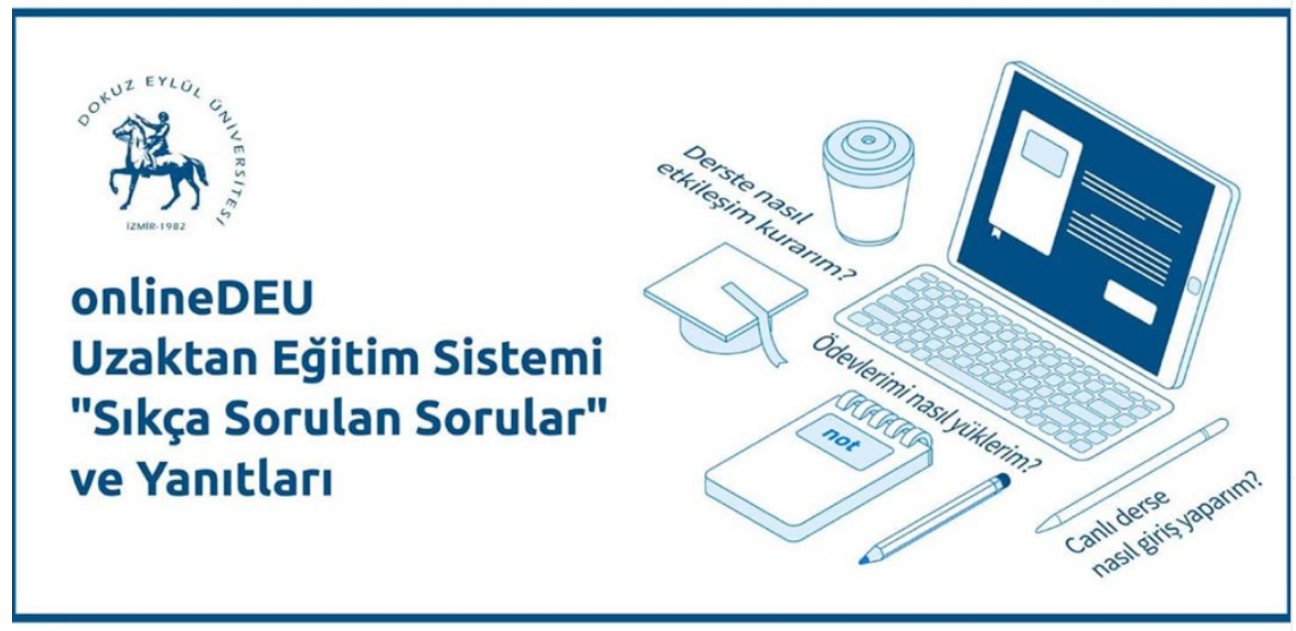

Görsel 7: Dokuz Eylül Üniversitesi sosyal medya paylaşımı örneği, 2020

Ülkenin büyük kesimi iletişimini internet ve akıllı telefonlarla sağlarken pandemi sürecinde de en çok tercih edilen ve en hızı geri dönüş alınan mecra sosyal medya ve internet olmuştur. Zaten evlerden çıkılamayan bu dönemde basılı ürünlere ulaşmak hem zor hem de virüs bulaşma tehlikesi nedeniyle tercih edilmemiştir. Bu noktada elimizin altından onlarca, yüzlerce bilgi kayıp giderken içlerinden dikkatimizi çeken ve merak uyandıran paylaşımların seçimi de bilgilendirme tasarımının görsel iletişim boyutuna da ne kadar dikkat edilmesi gerektiğinin göstermektedir. 

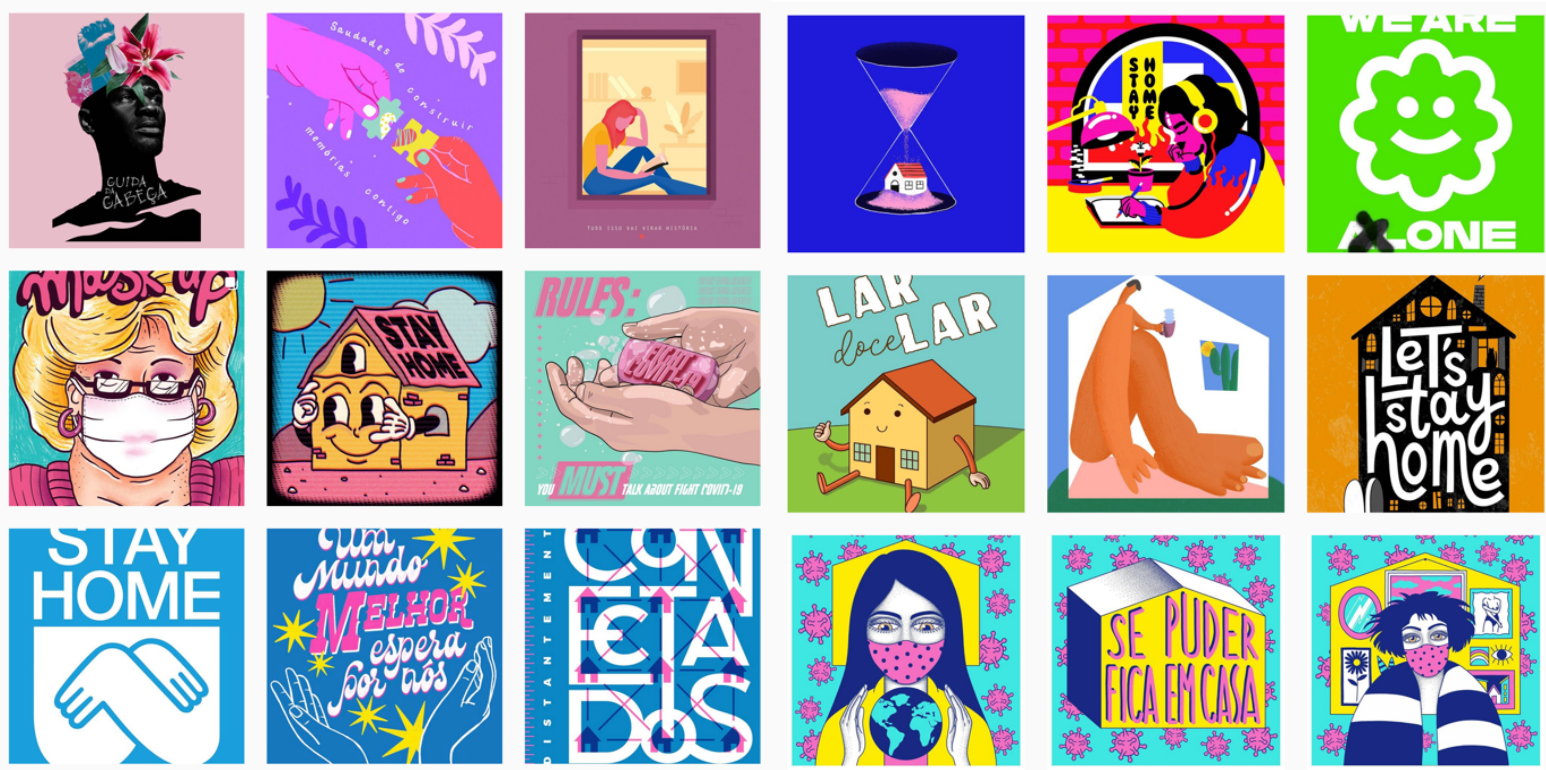

Görsel 8: Dünyanın farklı yerlerinden tasarımcıların Covid-19 ile ilgili tasarımlarının paylaşıldığı coviddesigners isimli sosyal medya hesabı, 2020
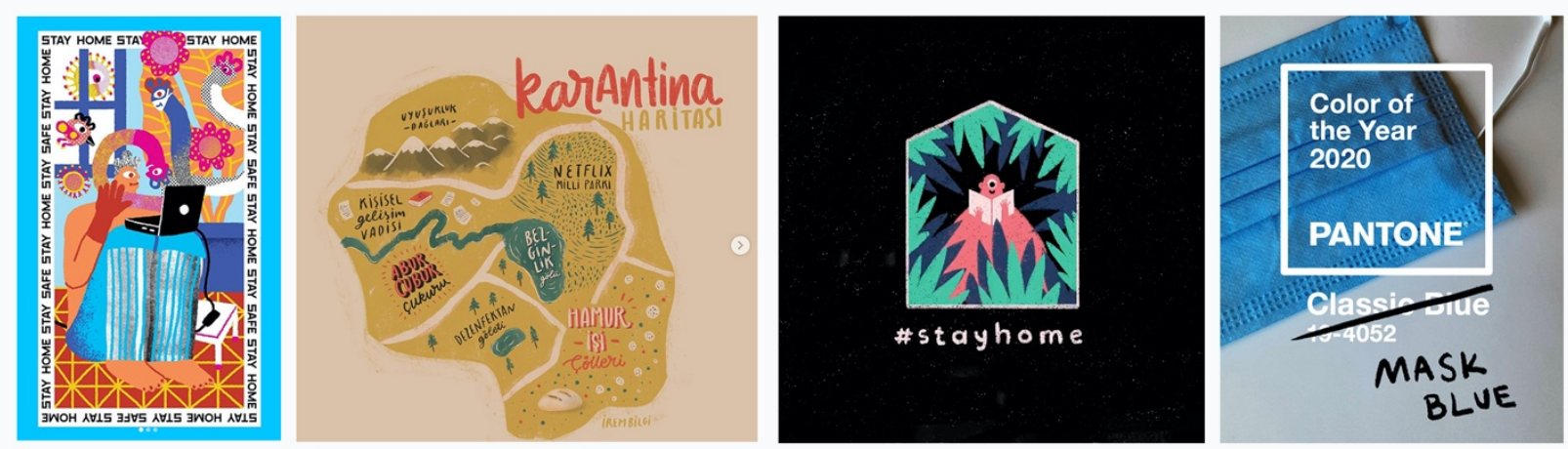

Görsel 9: Türk tasarımcıların Covid-19 ile ilgili kişisel hesaplarından

yaptıkları paylaşımlar, 2020

Soldan sağa: Uğur Altun, İrem Bilgi, Murat Kalkaman, Saydan Çelik

Sağlık Bakanlığı, kamu kurumları, üniversiteler ve özel şirketlerin zorunlu yayınları dışında birçok bağımsız tasarımcı ve çizer de evde kalma, karantina sürecinde evde yapılanlar, maske kullanımı, sosyal mesafe gibi konularda kendi tarzlarını yansıtan özgün çalışmalar yayınlamışlardır (Görsel 8-9). "Temelleri çok eskiye dayanan bilgilendirme tasarımı, günümüzde belli kural, kanun ve standartlara bağlı olsa da değişen dünyanın yeni taleplerine cevap verebilecek esneklikte ve yaratıcılıkta bir alan" (Oral, 2009:46). Sosyal mesafenin zorunlu olduğu ve tüm iletişimimizi internet ve telefon üzerinden yürüttüğümüz bu dönemde hem eğlenceli hem de bilgilendirici çalışmalar pandeminin kasvetli havasından sıyrılmayı sağlarken aynı zamanda insanların konunun öneminden uzaklaşmasını da engellemiştir. Evde kalmak salgının yayılmasını önlemek ve toplum sağlığını korumak için alınan önlemlerin başında gelmektedir. GMK (Grafikerler Meslek Kuruluşu) sosyal medya aracılığı ile "evde kal" tedbirini vurgulamak ve halkı bilinçlendirme çalışmalarına katkı sağlamak için üyelerine sıcağı sıcağına çağrıda bulunmuş, tasarımcılardan gelen çalışmaları yayınlayarak farkındalık oluşturmuştur (Görsel 10). 
INONU UNIVERSITY JOURNAL OF CULTURE AND ART / IJCA

İnönü Üniversitesi Kültür ve Sanat Dergisi

Volume/Cilt: 6 No/Sayı: 1 (2020) 1-13
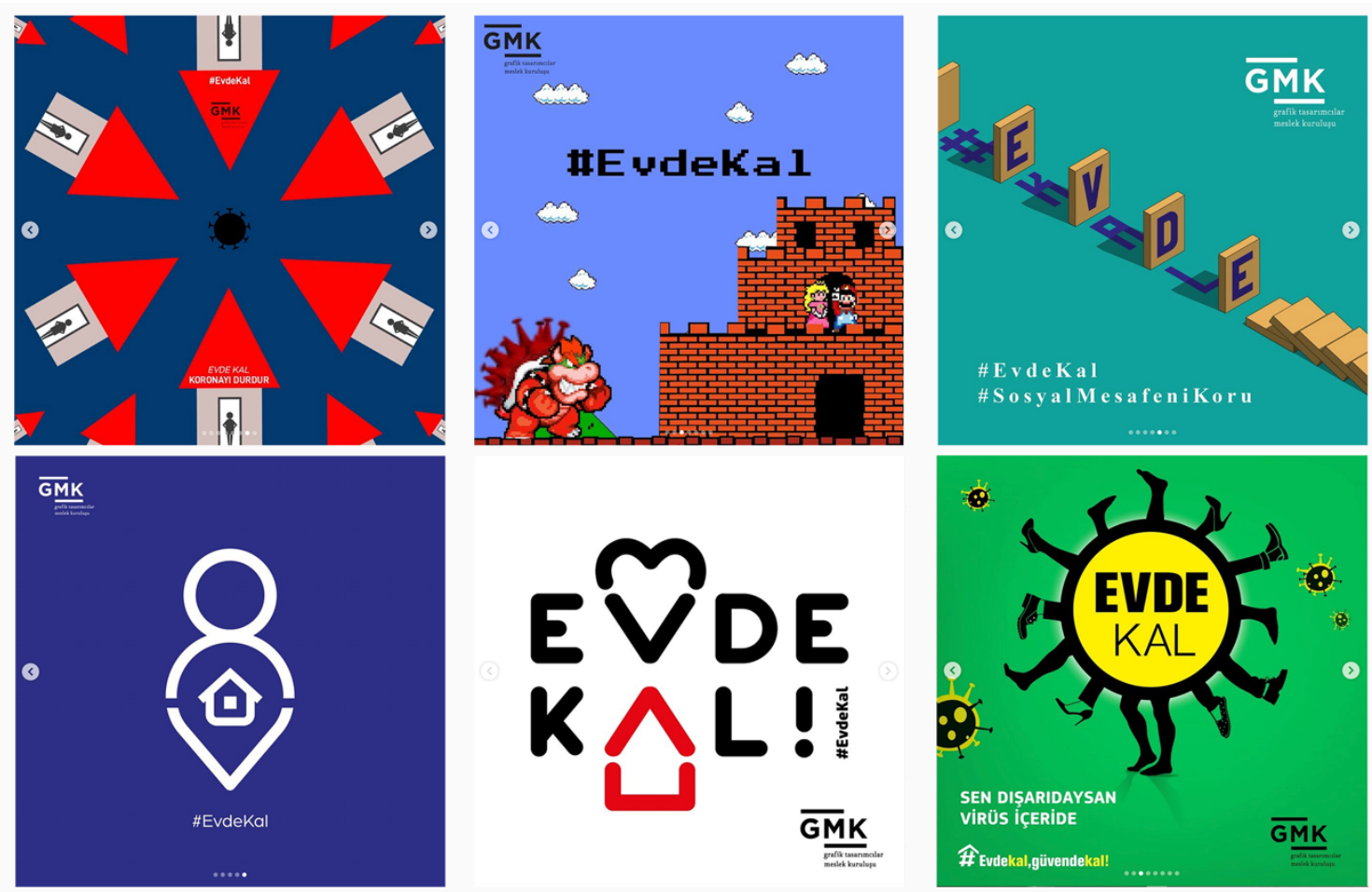

Görsel 10: GMK'nın üyelerine yaptığı çağıı sonucunda tasarımcılardan gelen Covid-19 ile ilgili çalışmalar, 2020

Üst sıra soldan sağa: Deniz Kürşad, Göksu Yeşilbaş, Taner Haydaroğlu,

Alt sıra Soldan Sağa: Ramazan Özkan, Murat Akkan, İbrahim Karaer

Benzer şekilde, pandemi ilan edildikten yaklaşık 10 gün sonra Birleşmiş Milletler (BM) tüm dünyadaki kreatiflere çağrıda bulunmuştur. Virüsten korunmak ve virüsün olası etkilerini en aza indirmek amacıyla tasarımcılardan yardım talep ederek "Dünyayı değiştirecek güce sahipsiniz. Bizim de önemli halk sağlığı mesajlarının, sadece farklı dillere çevrilmesi anlamında değil; farklı kültür, topluluk ve platformlara uyarlanması ve herkese, her yerde ulaştırıması için yardıma intiyacımız var," (talenthouse.com) diyen BM, paylaştığı brief'te altı maddeye vurgu yapmaktadır. Kişisel hijyen, sosyal mesafelenme, semptomlara ilişkin bilgi, iyiliğin yaygınlaştırılması, bilgi kirliliğinin önlenmesi, bağışların artırılması. Bu küresel çağrı sonucu dünyanın dört bir yanından gelen tasarımlar ise www.talenhouse.com üzerinden yayınlanmaktadır (Görsel 11).

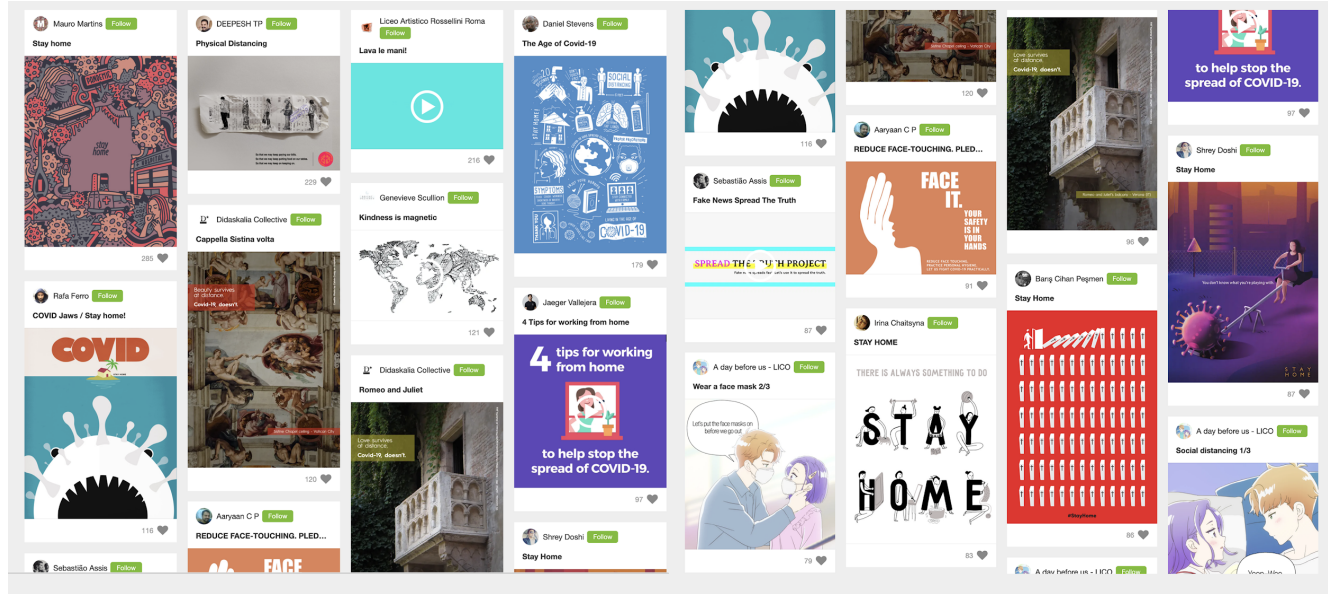

Görsel 11: Birleşmiş Milletler'in çağrısı sonucu tasarımcıların yayınladıkları

çalışmalardan bazıları, 2020 
Anadolu Üniversitesi Grafik Tasarım Bölümü öğretim elemanı Profesör Tevfik Fikret Uçar, "Evde kal" mottosu ile uluslararası bir dile sahip olan göstergeler tasarlayarak pandemi ilan edildiği günden itibaren düzenli olarak çalışmalar üretmiş ve kişisel hesaplarından paylaşmıştır (Görsel 12).
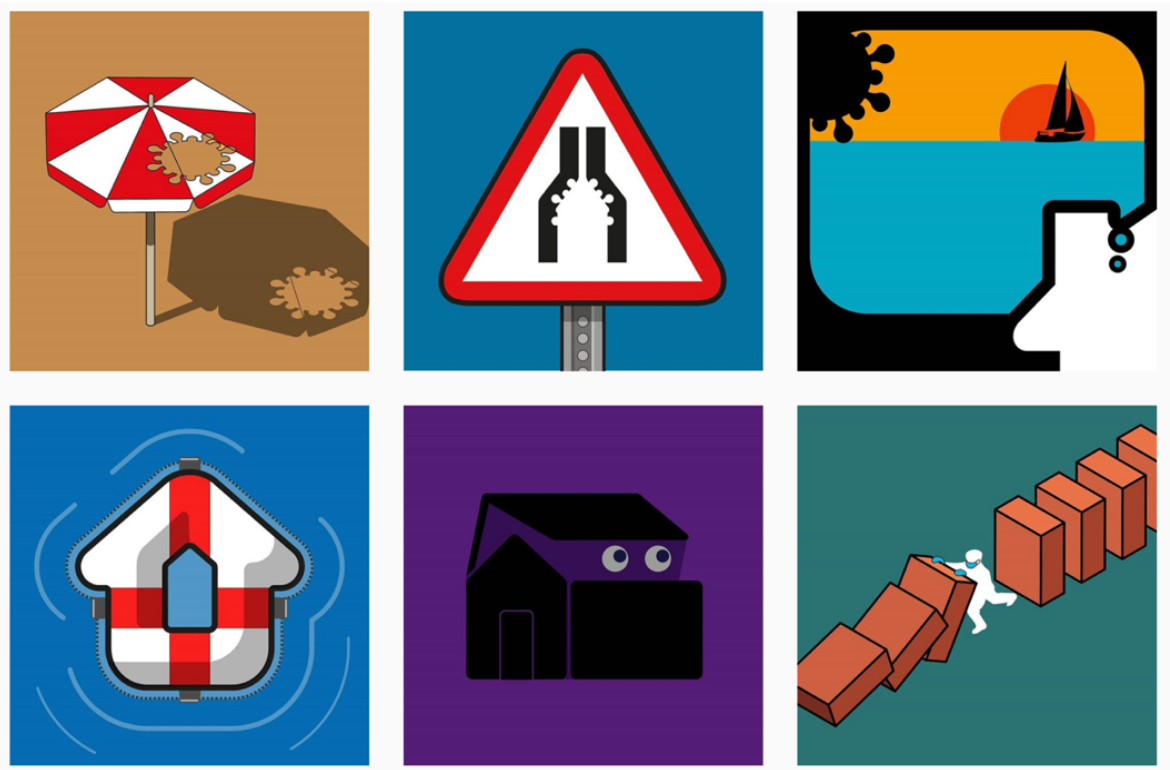

Görsel 12: Prof. Tevfik Fikret Uçar'ın pandemi sürecinde paylaştığı tasarımlarından bazıları

Aynı şekilde Mimar Sinan Üniversitesi Grafik Tasarım Bölümü'nde Öğretim Görevlisi olan Uğurcan Ataoğlu "Evde kal" teması ile pandemi sürecinde ara vermeden çalışmaya devam eden tasarımcılardan (Görsel 13).
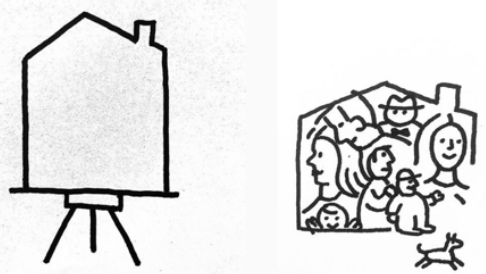

SO
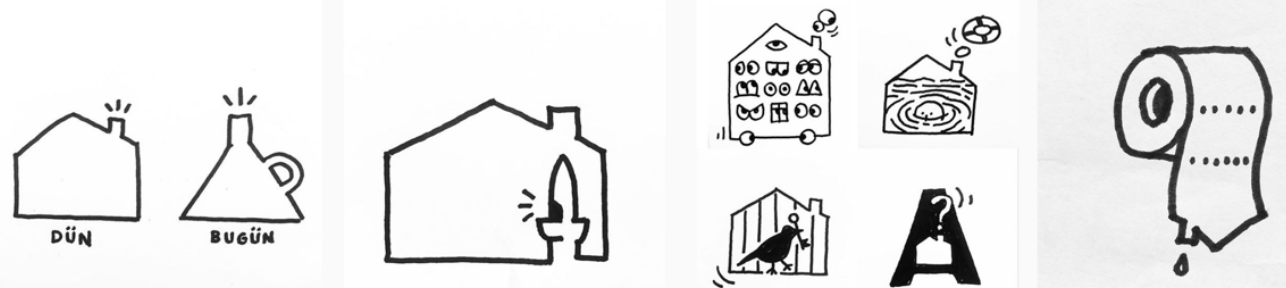

Görsel 13: Öğr. Gör. Uğurcan Ataoğlu'nun Covid-19 ile ilgili çalışmalarından bazıları, 2020

Anadolu Üniversitesi Grafik Tasarım Bölümü öğretim görevlisi Cemalettin Yıldız'ın süreç boyunca yaptığı esprili tasarımlar aynı zamanda uyarıcı ve bilgilendirici nitelik taşımaktadır (Görsel 14). 

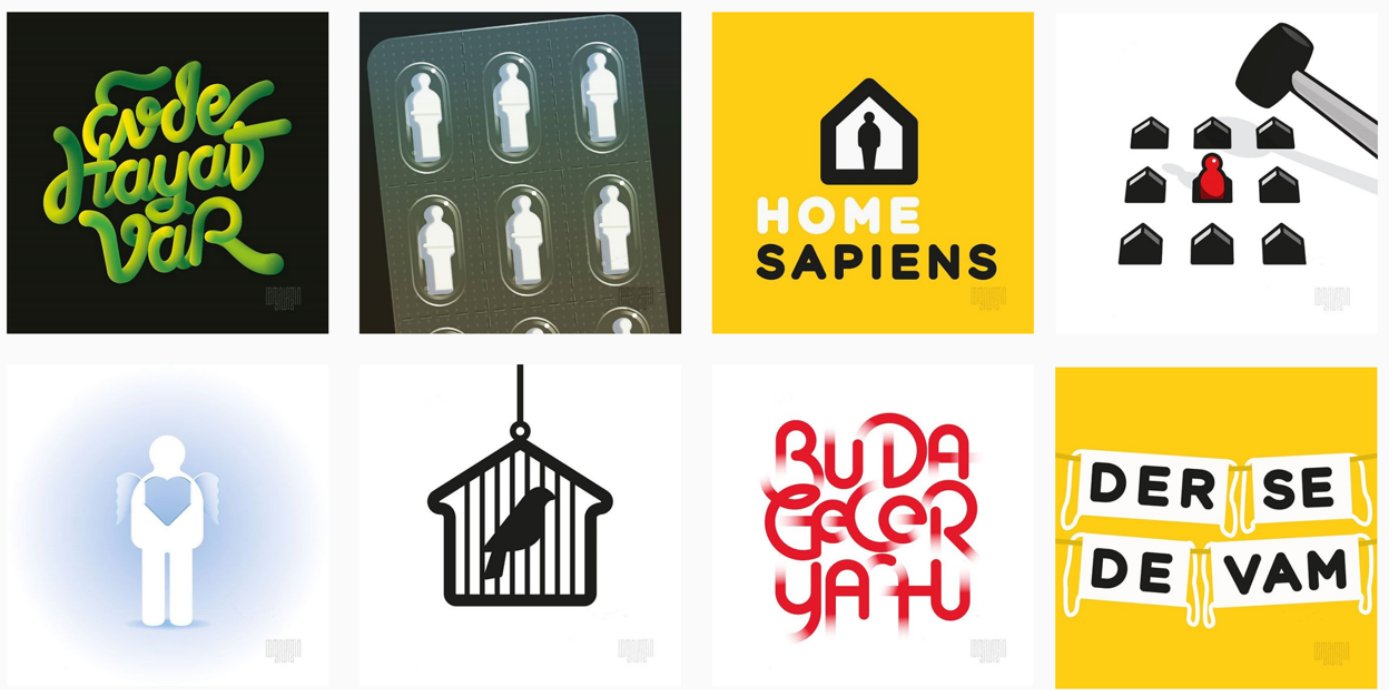

Görsel 14: Öğr. Gör. Cemalettin Yıldız'ın pandemi dönemi çalışmalarından örnekler, 2020

Dünya Doğayı Koruma Vakfı (WWF: World Wide Fund for Nature)'de takipçi kitlesine uygun bir dille tasarımlarında doğadaki dostlarımızı örnek göstererek "evde kal" mesajlarını paylaşmışlardır (Görsel 15).
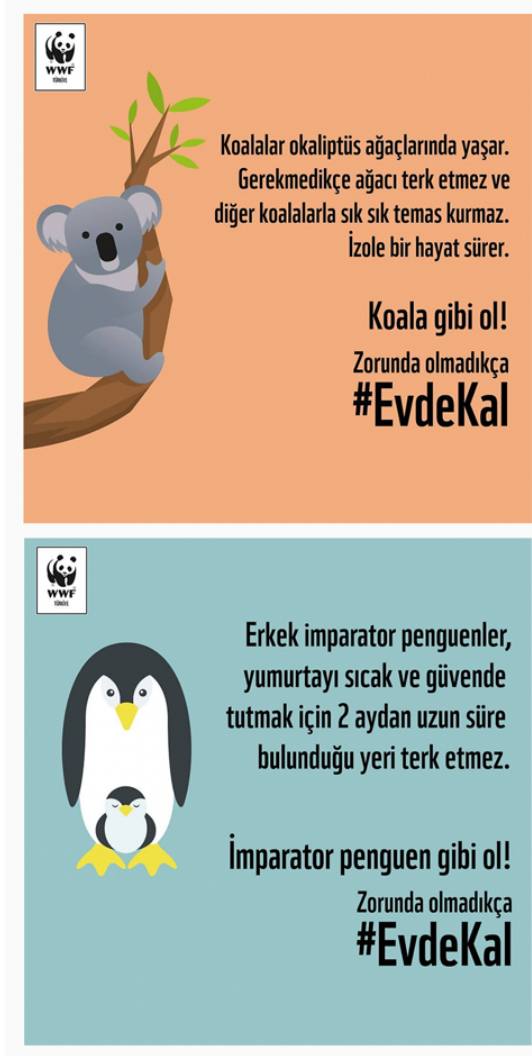
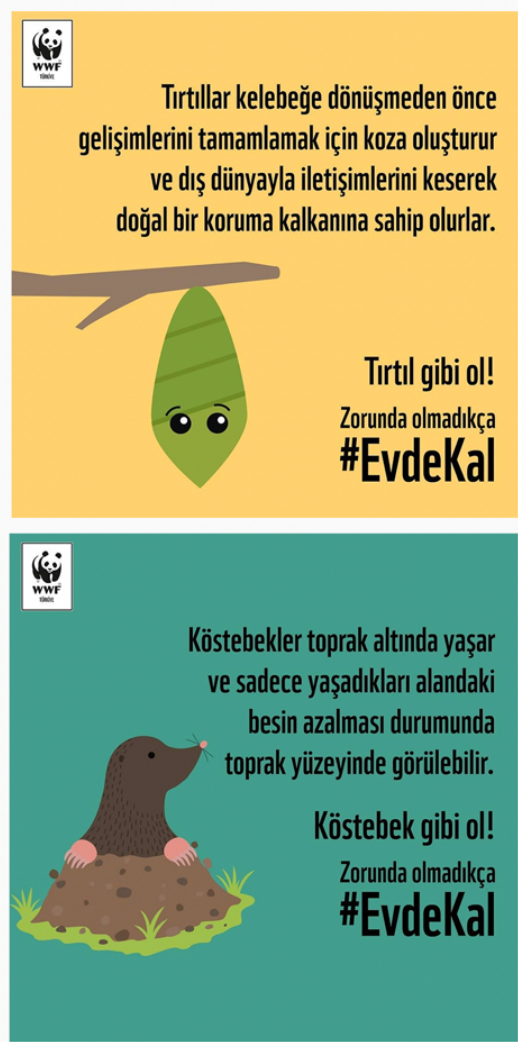
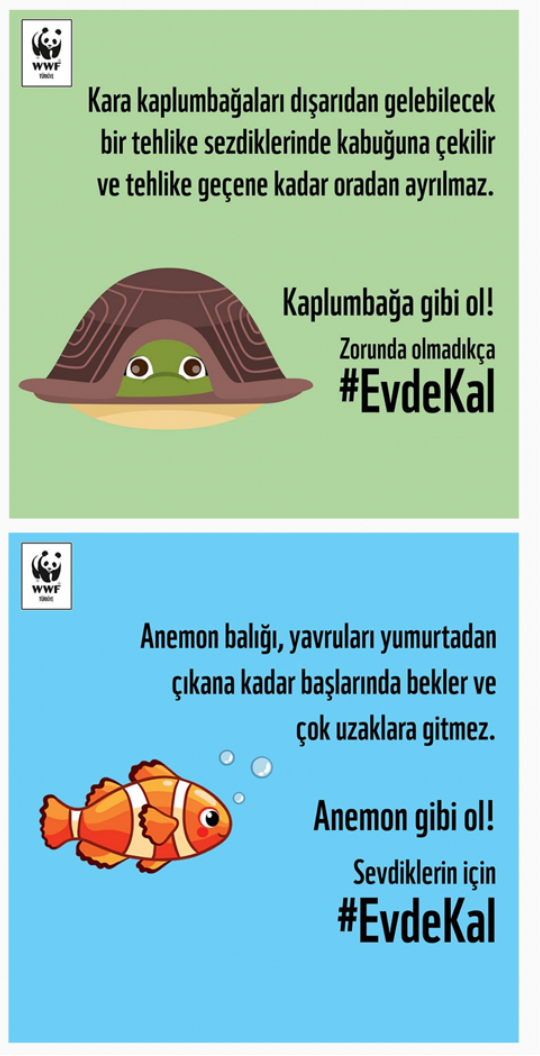

Görsel 15: WWF'in pandemic sürecinde yayınladığı “Evde Kal” mesajları, 2020 


\begin{abstract}
4.Sonuç
İnsanlık tarihinin başlangıcından itibaren bilgi hep değerli olmuş, sınırlı ve erişimi zor olan bilgiyi elinde tutanlar da onun gücüne sahip olup kullanmışlardır. Son yıllarda artan bilgi yoğunluğu ve gelişen iletişim teknolojileri bu durumu değiştirse de doğru ve gerekli bilgiye ulaşmak hala aynı derecede değerlidir. Temel iletişim intiyacı karşıııkı bilgi aktarımını getirirken aktarılan bilginin fazlalığı önemli olanların bazen arada kaybolmasına neden olmaktadır. Son yıllarda gelişen yeni iletişim teknolojileri de gün içinde yüzlerce bilginin elimizin altından kayıp gitmesine neden olurken içinden gerekli olanları seçmek daha da zor hale gelmektedir. Bilgilendirme tasarımı bu yoğun bilgi karmaşasının içinde bilgileri düzenleyip algılanmasını kolaylaştırırken içine yoğun bilgi bombardımanı içinde gerekli olanların hızla algılanmasını sağlamaktadır.

Küresel bir salgın haline gelen Covid-19 yüzünden 11 Mart'ta pandemi ilan edilmiş ve tüm dünya evine kapanmıştır. Bilgi alma ihtiyacının en yüksek seviyede olduğu bu kriz döneminde neredeyse tek iletişim kaynağı olan internet aynı zamanda temel bilgi kaynağı haline dönüşmüş ve doğru bilgiler kadar yanlış bilgiler de hızla yayılarak insanların hayatını tehlikeye atacak boyuta ulaşmıştır. Bu süreçte en çok ihtiyaç duyulan ve kullanılan iletişim ve tasarım disiplini olan bilgilendirme tasarımı hızlı ve herkes tarafından anlaşılabilen içeriklerin paylaşıımasını sağlamıştır. Herkesin korktuğu bu süreçte halkın doğru ve güvenilir bilgilere açık ve anlaşıır bir biçimde ulaşmasında tasarımcılara da büyük sorumluluk düşmektedir.

Sonuç olarak; iyi hazırlanmış bilgilendirme tasarımı, çevrede bulunan karmaşık verilerden gerekli olanları açık ve dikkat çekici şekilde sunarak hayatı kolaylaştırmakta, yanlış anlaşılmalardan doğabilecek hasarların önüne geçmektedir. Pandemi gibi kriz dönemlerinde bilgi karmaşasını önlemek ve toplumu doğru yönlendirebilmek için için bilgilendirme tasarımına ve tasarımcılara büyük sorumluluklar düşmektedir.
\end{abstract}

\title{
Kaynakça
}

Covid-19 (Sars-CoV-2 Enfeksiyonu) Rehberi, Bilim Kurulu Çalışması, Ankara, T.C. Sağlık Bakanlığı, Halk Sağlığı Genel Müdürlüğü, 2020

Güler, Tuğcan. Grafik Tasarımda Yeni Bir Alan: Bilgilendirme Tasarımı. İzmir, Dokuz Eylül Üniversitesi, Güzel Sanatlar Enstitüsü, Sanatta Yeterlilik Tezi. 2008

Horn, Robert E. Bilgilendirme Tasarımı: Yeni Bir Mesleğin Doğuşu, Grafik Tasarım Dergisi, Sayı 28, 30-39.

Jean, G. (2018). Yazı İnsanlığın Belleği. (Çev. N. Başer). İstanbul:Yapı Kredi Yayınları.

Karamustafa, S. (2003). 21. Yüzyıl Türkiye'sinde Görsel İletişim Tasarımı Eğitimi. Gelişmiş İletişim Teknolojileri Çağında, Türkiye'deki Grafik Tasarım Eğitiminin Geleceğine İlişkin Bir Model Önerisi. Yayımlanmamış Sanatta Yeterlik Tezi. İstanbul: Mimar Sinan Üniversitesi.

Oral, Gözde. Bilgi Güçtür, Grafik Tasarım Dergisi, Sayı 28, 46-47.

Pektaş Turgut, Özden. Elektronik Yayımcılık Biçimleri ve Blog Tasarımı, Gazi Üniversitesi Sanat ve Tasarım Dergisi, 2009, 89

Pettersson, R. (2015). Information Design It Depends. Tullinge.

Schuller, G. (2007). Information Design = Complexity + Interdisciplinarity +

Experiment. AIGA - CLEAR - The Journal of Information Design (Elektronik Bülten).

Spiekermann, Erik. 2009, Bilgilendirme Tasarımı. Grafik Tasarım Dergisi, Sayı 28, 44-45

Teker, Ulufer. (2002). Grafik Tasarım ve Reklam. İzmir: Dokuz Eylül Yayınları.

Uyan Dur, Banu İnanç. Bilgilendirme Tasarımında İlkeler, Öğeler ve Uygulama Sorunları "Bilgilendirme Tasarımı Uygulaması", Ankara, Hacettepe Üniversitesi, Sosyal Bilimler Enstitüsü, Sanatta Yeterlilik Tezi, 2011 
INONU UNIVERSITY JOURNAL OF CULTURE AND ART / IJCA

Inönü Üniversitesi Kültür ve Sanat Dergisi

Volume/Cilt: 6 No/Sayı: 1 (2020) 1-13

\section{İnternet Kaynakları}

Pandemi, https://tr.wikipedia.org/wiki/Pandemi Erişim Tarihi: 1 Haziran 2020

Teyit.org,https://teyit.org/yeni-koronavirusun-akcigere-inmeden-once-dort-gun-bogazda-kaldigi-iddiasi/)

Erişim Tarihi: 3 Haziran 2020

Birleşmiş Milletler Çağrısı,

https://www.talenthouse.com/i/united-nations-global-call-out-to-creatives-help-stop-the-spread-of-covid-19

Erişim Tarihi: 3 Haziran 2020

\section{Görsel Kaynakları}

Görsel 1: https://dsourcechallenge.org/results.html\#results, Erişim Tarihi: 2 Haziran 2020

Görsel 2: https://www.who.int/emergencies/diseases/novel-coronavirus-2019, Erişim Tarihi: 30 Mayıs 2020

Görsel 3: https://covid19.saglik.gov.tr/ Erişim Tarihi: 30 Mayıs 2020

Görsel 4: https://covid19.saglik.gov.tr/ Erişim Tarihi: 30 Mayıs 2020

Görsel 5: https://covid19.saglik.gov.tr/ Erişim Tarihi: 30 Mayıs 2020

Görsel 6:

https://gisanddata.maps.arcgis.com/apps/opsdashboard/index.html\#/bda7594740fd40299423467b48e9ecf6

Erişim Tarihi: 13 Haziran 2020

Görsel 7: https://www.instagram.com/p/B-r2AP8JSrQ/ Erişim Tarihi: 30 Mayıs 2020

Görsel 8: https://www.instagram.com/covidesigners/ Erişim Tarihi: 1 Haziran 2020

Görsel 9: https://www.instagram.com/p/B-MOHuVA1ZR/, https://www.instagram.com/p/B_dQKImgD6X/, https://www.instagram.com/p/B-Ek_4nAs9p/, https://www.instagram.com/p/B_NaGbIA0Jr/Erişim Tarihi: 10 Haziran 2020

Görsel 10: https://www.instagram.com/p/B-fGxB4A8xO/ Erişim Tarihi: 10 Haziran 2020

Görsel 11: https://www.talenthouse.com/i/1839/submission/418869/7a95c9cc Erişim Tarihi: 2 Haziran 2020

Görsel 12: https://www.instagram.com/grafikret/ Erişim Tarihi: 1 Haziran 2020

Görsel 13: https://www.instagram.com/howareyoubob/ Erişim Tarihi: 1 Haziran 2020

Görsel 14: https://www.instagram.com/cemalettn_yildiz/ Erişim Tarihi: 1 Haziran 2020

Görsel 15: https://www.instagram.com/wwf_turkiye/ Erişim Tarihi: 10 Haziran 2020 